\title{
Hasil Seni Bangun Bergaya Indis: Studi Kasus Kelestarian Sejumlah Benteng di Jawa Tengah
}

\section{Novida Abbas}

Keywords: dutch, fortress, java, description, planning, conservation, colonial archaeology

\section{How to Cite:}

Abbas, N. (1998). Hasil Seni Bangun Bergaya Indis: Studi Kasus Kelestarian Sejumlah Benteng di Jawa Tengah. Berkala Arkeologi, 18(2), 37-46. https://doi.org/10.30883/jba.v18i2.782

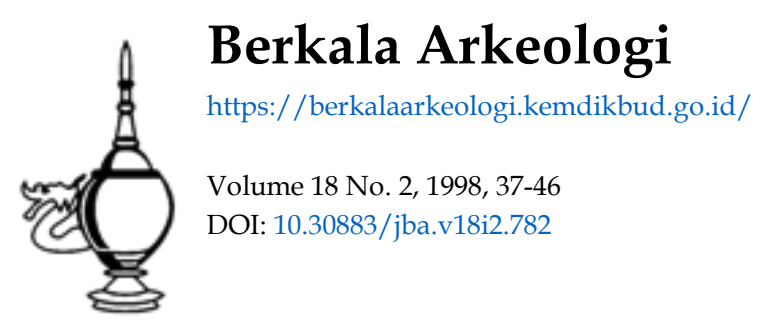

\section{c) (7)(2)}

This work is licensed under a Creative Commons Attribution-NonCommercial-ShareAlike 4.0 International License. 


\section{HASIL SENI BANGUN BERGAYA INDIS \\ Studi Kasus: Kelestarian Sejumlah Benteng di Jawa Tengah" \\ Novida Abbas \\ (Balai Arkeologi Yogyakarta)}

\section{PENDAHULUAN}

\subsection{Permasalahan}

Berbagai hasil seni bangun bergaya Indis cukup banyak dijumpai di berbagai wilayah di Indonesia. Bangunan-bangunan tersebut sampai kepada kita dalam berbagai bentuk, yang dapat dibedakan atas bangunan-bangunan yang penggunaannya bersifat pribadi dan bersifat umum (Soekiman, 1996: 156). Yang pribadi terutama adalah bangunanbangunan rumah tinggal dan pesanggrahan/tempat peristirahatan. Sementara yang penggunaannya bersifat umum (public) meliputi bangunan perkantoran, sekolah, gereja, kompleks pemakaman, dan fasilitas umum lainnya. Selain itu terdapat pula bangunan-bangunan yang penggunaannya khusus untuk kepentingan militer, misalnya tangsi dan benteng.

Perkembangan dari motivasi ekonomi menjadi ekspansi politik yang dilancarkan oleh bangsa-bangsa barat pada abad-abad lampau itu mengakibatkan terjadinya serangkaian perlawanan rakyat di berbagai daerah (Tjandrasasmita, 1984: 45--46). Untuk menanggulangi perlawanan rakyat itu, baik Portugis, Belanda, maupun Inggris mendirikan sejumlah bangunan pertahanan di berbagai tempat. Sebagai contoh pendirian Benteng Zeelandia dan Deeurstede di Ambon untuk menanggulangi perlawanan Thomas Matulessi (Soetjipto, 1975: 126--140), juga pendirian Benteng Vredeburg di Yogyakarta pada tahun 1759 untuk mengawasi aktivitas Kraton Yogyakarta (Hatmosuprobo, 1979: 150--153). Di samping itu, meletusnya Perang Diponegoro di Jawa Tengah pada abad XIX mengakibatkan Belanda melancarkan sistem benteng (benteng stelsel) sejak tahun 1827 (Hooyer, 1896: 99).

Di beberapa daerah di Jawa Tengah bekas benteng-benteng Belanda (dan Portugis ?) masih dapat disaksikan hingga kini dalam jumlah yang cukup banyak dengan bentuk maupun keletakan yang beragam. Benteng-benteng tersebut merupakan salah satu jenis tinggalan arkeologis dari masa kolonial Belanda di Indonesia yang memiliki keterkaitan

Penah dipresentasikan dalam Diskusi Ilmiah Arkeologi VIII yang diselenggarakan oleh LAAI Komda DI Yogyakarta dan Jawa Tengah dengan Tema Pelestarian dan Pemanfaatan Bangunan Indis di Museum Benteng Yogyakarta, tanggal 9 Agustus 1997. 
erat dengan sejarah perjuangan bangsa Indonesia, dan selain itu dengan mengacu pada UU RI No. 5/1992 diketahui bahwa benteng-benteng tersebut juga merupakan salah satu Benda Cagar Budaya (BCB). Meskipun termasuk dalam kategori BCB, namun pada kenyataannya sebagian besar benteng di Jawa Tengah tersebut belum diperlakukan sebagai BCB karena berbagai sebab.

Dalam makalah ini akan dipaparkan mengenai keberadaan dan kondisi fisik sejumlah benteng di Jawa Tengah. Penyajian ini didasarkan atas fakta yang dijumpai di lapangan sebagai realisasi dari penelitian yang telah dilakukan oleh Balai Arkeologi Yogyakarta di Jawa Tengah dan Jawa Timur dalam tahun 1993--1996 (Abbas, 1993/1994; 1994/1995: 1995/1996: 1996/1997).

\subsection{Maksud dan Tujuan}

Kajian tentang aspek kelestarian benteng-benteng dari masa kolonial Belanda ini dilandasi dengan tujuan untuk menginformasikan kondisi sejumlah benteng tersebut saat ini. Selain itu juga akan disinggung mengenai potensi yang terkandung di dalamnya. Melalui penyajian ini diharapkan dapat diperoleh gambaran langkah yang sebaiknya dilakukan dalam mengupayakan pelestarian maupun (nantinya) pemanfaatan yang mungkin dapat diterapkan pada benteng-benteng tersebut.

\section{KEBERADAAN DAN KONDISI BENTENG "INDIS" DI JAWA TENGAH}

Bekas benteng yang menjadi obyek bahasan berjumlah 10 buah, yaitu masing-masing terdapat di Jepara, Surakarta, Ambarawa, Ungaran, Cilacap, Pekalongan, Gombong, dan Salatiga. Sembilan di antaranya merupakan bekas benteng Belanda, sedangkan 1 merupakan bekas benteng Portugis (?). Sejumlah benteng diketahui masa pendiriannya, sementara beberapa di antaranya belum diketahui dengan pasti masa pendiriannya. Benteng-benteng yang diketahui data pertanggalannya berasal dari abad XVII=-XIX.

\subsection{Jepara}

Di wilayah Kabupaten Jepara terdapat dua benteng, yaitu sebuah bekas benteng Belanda di Desa Ujung Batu, Kecamatan Jepara dan sebuah bekas benteng Portugis (?) di Desa Banyumanis, Kecamatan Keling. Benteng Belanda tersebut berasal dari sekitar abad XVII (Olthof, 1941: 165 dan Graaf, 1987: 94--95) dan memiliki denah segi tiga (Abbas, 1994). Sementara benteng Portugis (?) belum diketahui masa pendiriannya dan 
berdenah trapesium. Bekas benteng Belanda maupun benteng Portugis tersebut saat ini telah tidak digunakan lagi. Terakhir benteng Belanda yang terletak di puncak bukit di tepi Laut Jawa itu digunakan oleh TNI AD dan saat ini dibiarkan terbengkalai. Dinding keliling benteng beserta bastionnya sebagian besar telah runtuh. Sementara itu bekas benteng Portugis telah dimanfaatkan oleh pihak pariwisata setempat, yaitu sebagai obyek wisata, mengingat keletakannya di puncak bukit di tepi laut yang cukup menunjang pemanfaatannya sebagai obyek wisata. Sejumlah sarana penunjang telah dibangun di bagian dalam benteng, misalnya saja fondasi bekas salah satu bastion digunakan untuk mendirikan semacam gazebo permanen, sementara di bagian lain di dalam benteng juga telah dipasang sarana bermain anak-anak. Sebenarnya di bagian dalam benteng ini masih terdapat sejumlah fondasi bangunan, dan saat ini fondasifondasi tersebut telah tertutup oleh beberapa bangunan baru tersebut di atas.

\subsection{Surakarta}

Di Surakarta terdapat sebuah bekas benteng Belanda di Kelurahan Kampung Baru, Kecamatan Pasar Kliwon, yaitu Benteng Vastenburg, yang didirikan pada sekitar abad XVIII, pada masa pemerintahan Sunan Pakubuwono II (1726--1749). Benteng yang terletak di sebelah timur laut Kraton Surakarta ini berdenah segi empat. Terakhir benteng ini digunakan sebagai markas dan asrama Brigif 6, dan sekarang berada di bawah pengelolaan PT Pondok Solo Permai (Suara Merdeka, 1994). Bekas benteng ini sekarang hanya tersisa tembok kelilingnya saja, sementara bangunan-bangunan di bagian dalam benteng telah dirubuhkan. Menurut keterangan pihak pengelola saat ini, bekas benteng ini direneanakan akan digunakan sebagai hotel dengan tidak menghilangkan tembok keliling tersebut (bangunan hotel akan didirikan di bagian dalam tembok keliling).

\subsection{Ambarawa}

Sebuah bekas benteng Belanda, yaitu Benteng Willem I, terdapat di Kelurahan Ambarawa, Kecamatan Ambarawa (Kota). Benteng ini dikenal oleh masyarakat setempat sebagai Benteng Pendem, karena sebagian bangunannya sengaja dibuat tersembunyi di bawah tanah. Benteng yang berasal dari abad XIX ini secara keseluruhan berdenah segi empat dan keseluruhannya mencakup areal seluas 3,2 ha. Bangunan utama benteng ini berlantai dua. Saat ini kompleks benteng tersebut digunakan sebagai rumah tahanan militer di bawah Kodam IV Diponegoro. Dari keseluruhan bangunan yang ada di kompleks ini hanya sebagian kecil yang digunakan sebagai kantor, ruang tahanan, dan tempat tinggal karyawan. Sebagian besar bangunan 
dibiarkan kosong sementara beberapa bagian lainnya ditutup dengan semen (permanen) untuk sarang burung walet, terutama bangunan-bangunan yang dulunya merupakan gudang amunisi dan menara penjagaan. Bagian bangunan lainnya yang tidak digunakan saat ini mulai rusak dan runtuh, misalnya saja lorong di lantai dua, atap, dan bangunan sel bawah tanah.

\subsection{Ungaran}

Di Desa Ungaran. Kecamatan Ungaran terdapat sebuah bekas benteng Belanda, yaitu Benteng Willem II. Benteng seluas 0,2 ha ini terletak di tepi jalan raya yang menghubungkan Semarang dengan Ambarawa dan berdenah bujur sangkar. Benteng yang berasal dari abad XVIII ini (Darmosoetopo, 1983: 13--14) sekarang digunakan sebagai asrama polisi. Karena digunakan sebagai tempat tinggal, dengan sendirinya telah terjadi beberapa perubahan pada bangunan benteng ini, baik berupa penambahan maupun pengurangan.

\subsection{Cilacap}

Di Cilacap terdapat dua bekas benteng Belanda, yaitu Benteng Pendem yang terletak di Kelurahan Cilacap, Kecamatan Cilacap Selatan, dan Benteng Karangbolong yang terletak di Pulau Nusakambangan, tepatnya di wilayah Kelurahan Tambakreja, Kecamatan Cilacap Selatan. Benteng Pendem yang didirikan pada abad XIX ini pada awalnya berdenah segi lima dan terletak di areal seluas 10 ha, namun saat ini yang tersisa hanya 6,5 ha. Saat ini Benteng Pendem telah dimanfaatkan sebagai obyek wisata di bawah pengelolaan Dinas Pariwisata setempat. Bekas areal benteng yang 3,5 ha tersebut telah menjadi milik Pertamina dan di tempat itu telah didirikan sejumlah bangunan perkantoran maupun tangki-tangki penyimpanan minyak. Selain itu dalam upaya pengelolaannya, Dinas Pariwisata secara bertahap juga masih melakukan pengupasan terhadap bagian-bagian benteng yang masih terpendam dalam usaha menampakkan sejumlah elemen benteng. Sementara itu, Benteng Karangbolong yang terletak di tepi timur-laut Pulau Nusakambangan belum diketahui denah aslinya, hanya diketahui bahwa benteng ini berlantai empat (dihitung dari lantai bawah tanahnya). Masa pendirian benteng ini juga belum diketahui. Benteng tersebut saat ini berada dalam keadaan terbengkalai dan tertutup cukup rapat oleh vegetasi yang tumbuh di sekitamya. Benteng yang sebagian bangunannya juga dibuat terpendam di dalam tanah ini keadaannya cukup memprihatinkan, karena lantai-lantai kayu maupun lantai-lantai bata di beberapa bagian benteng telah diambili, padahal sebenarnya bentuk fisik benteng secara keseluruhan masih relatif utuh. 


\subsection{Pekalongan}

Sebuah bekas benteng Belanda berdenah jajaran genjang terletak di wilayah Kelurahan Panjang Wetan, Kecamatan Pekalongan Utara. Benteng yang tidak diketahui tahun pendiriannya ini aslinya di bagian dalamnya memiliki sejumlah bangunan berupa barak prajurit, ruang tahanan, dan sociteit. Bekas benteng tersebut saat ini digunakan sebagai Rumah Tahanan Negara. Dalam fungsinya sebagai Rumah Tahanan Negara tersebut bangunan benteng ini telah mengalami perubahan-perubahan, misalnya saja pembongkaran dua dari tiga bastion untuk dijadikan menara pengawasan serta penambahan bangunan-bangunan baru di dalam maupun di luar tembok keliling.

\subsection{Gombong}

Di wilayah desa Sidayu, Kecamatan Gombong, terdapat sebuah bekas benteng Belanda yang berdenah segi delapan dan berlantai dua. Masa pendirian benteng ini belum diketahui. Dulunya benteng ini digunakan sebagai tempat pendidikan dan latihan serdadu Belanda sekaligus sebagai tempat perbekalan (logistik). Di kompleks ini juga terdapat bangunan-bangunan lain yang dulunya digunakan sebagai tempat tinggal para serdadu maupun bangunan perkantoran. Seluruh kompleks saat ini digunakan untuk Secatam (Sekolah Calon Tamtama) Rindam IV di bawah Kodam IV/Diponegoro. Khusus untuk bangunan utama benteng yang berlantai dua yang telah disebutkan di atas digunakan untuk tempat tinggal para anggota Secatam dan saat ini hanya dihuni oleh lima keluarga. Kondisi benteng berlantai dua ini relatif utuh, meskipun beberapa bagian bangunannya ada yang rusak, mengingat sebagian besar tidak dihuni lagi.

\subsection{Salatiga}

Di pinggir kota Salatiga, yaitu pada pertigaan jalan utama yang merupakan jalur Semarang-Salatiga-Boyolali terdapat sebuah bekas benteng Belanda.- Secara keseluruhan bekas benteng ini berdenah empat persegi panjang. Dulunya keseluruhan kompleks dikelilingi tembok, yang sekarang sebagian besar telah runtuh. Di bagian dalam terdapat sejumlah bangunan, yang antara lain terdiri atas sejumlah loji, ruang tahanan, kamar bola, dan gudang mesiu. Benteng yang didirikan pada abad XIX ini dulu digunakan sebagai tangsi dan sekaligus tempat melatih kuda milik pasukan kavaleri Belanda. Saat ini bekas benteng tersebut digunakan sebagai gudang beras dan sekaligus asrama Brigade Infantri 411 Kostrad dan dikenal oleh masyarakat sekitarnya dengan sebutan "Tebek" (tempat perbekalan). Bekas benteng ini dapat dikatakan relatif 
utuh, hanya beberapa bagian bangunannya telah runtuh, misalnya tembok keliling. Selain itu juga terdapat sejumlah penambahan bangunan baru.

Selain benteng-benteng yang telah dipaparkan di atas, terdapat pula sebuah bekas benteng di Boyolali, yaitu Benteng Renovatum (Humas Dati II Kabupaten Boyolali, tanpa tahun), yang saat ini hanya tersisa sebagian taludnya dan tiang benderanya saja. Benteng ini telah diruntuhkan seluruhnya pada tahun 1953 dan saat ini areal bekas benteng tersebut digunakan sebagai lokasi taman bermain, wartel, gedung arca, dan berbagai sarana olahraga.

\section{PEMBAHASAN}

Membicarakan keberadaan sejumlah benteng di berbagai tempat --khususnya di Jawa Tengah-- secara umum tampak bahwa kelestariannya cukup memprihatinkan dan belum sepenuhnya mendapat perhatian yang selayaknya. Terlihat bahwa beberapa benteng yang letaknya di tengah kota cenderung terlanda oleh berbagai kepentingan pembangunan, misalnya Benteng Vastenburg di Surakarta dan Benteng Renovatum di Boyolali. Sementara itu benteng-benteng lainnya meskipun belum hilang sama sekali, kondisinya cukup memprihatinkan dan "terancam" dalam bentuk lain, seperti pemanfaatannya untuk sarang walet, penambahan dan atau pengurangan bangunan, maupun dibiarkan terbengkalai.

Memang belum pernah dilakukan analisis terhadap potensi sumberdaya arkeologi yang berupa bekas benteng-benteng tersebut di atas, kecuali (mungkin) Benteng Pendem di Cilacap -- mengingat benteng tersebut saat ini telah dimanfaatkan-- dan Benteng Willem II di Ungaran (Darmosoetopo, 1983). Meskipun demikian, secara garis besar akan dicoba untuk menjabarkan nilai penting benteng-benteng tersebut sebagai suatu sumberdaya arkeologi. Setidak-tidaknya benteng-benteng tersebut memiliki nilai penting kesejarahan, ilmu pengetahuan, dan sosial ekonomi. Aspek kesejarahan adalah sejauh mana sumberdaya arkeologi itu dilatarbelakangi oleh peristiwa bersejarah yang dianggap penting serta yang berkaitan secara simbolis dengan peristiwa terdahulu. Aspek ilmu pengetahuan adalah sejauh mana sumberdaya arkeologi tersebut memiliki deposit mutu serta keluasan dalam pengembangan ilmu pengetahuan. Selanjutnya aspek sosial ekonomi adalah sejauh mana peran penting sumberdaya arkeologi tersebut bagi aspek-aspek nilai dan kehidupan masyarakat, misalnya pendidikan, jati diri, dan citra kawasan. Selain itu sejauh mana akses maupun nilai komersial sumberdaya arkeologi tersebut dalam meningkatkan pendapatan ekonomis bagi suatu tempat, misalnya pariwisata. Dua aspek penting pertama di atas mengacu pada ketentuan pasal 1 UURI No. 5/1992 tentang Benda Cagar Budaya, sementara nilai penting terakhir 
mengacu pada analisis nilai penting yang pada umumnya dilakukan dalam manajemen sumberdaya arkeologi/budaya (Schiffer \& Gummerman, 1977: 241--248).

Dari segi kesejarahan, benteng-benteng tersebut di atas memiliki nilai historis yang cukup tinggi, mengingat keberadaan benteng-benteng tersebut merupakan bukti adanya perlawanan dari rakyat Indonesia terhadap penjajahan. Sementara itu dari segi ilmu pengetahuan, keberadaan benteng-benteng itu juga memiliki kualitas tersendiri, misalnya di bidang arsitektur, khususnya mengenai bangunan-bangunan pertahanan. Di bidang sosial ekonomi tinggalan berupa benteng dapat dimanfaatkan untuk kepentingan pengajaran tentang sejarah kebudayaan dan sejarah arsitektur, di samping itu dapat pula dimanfaatkan sebagai obyek wisata budaya.

Meskipun cukup penting untuk dapat dimanfaatkan dalam berbagai bidang, namun pada kenyataannya hingga saat ini kondisi bangunan bergaya Indis yang berupa benteng-benteng tersebut cukup memprihatinkan. Hal ini tentunya tidak dapat dilepaskan dari fakta bahwa sebagian besar bangunan benteng tersebut hingga saat ini masih digunakan oleh pihak ABRI, meskipun kadar penggunaannya relatif rendah, dalam arti dari keseluruhan kompleks suatu benteng hanya sebagian kecil yang benarbenar digunakan, sementara sebagian besar lainnya dibiarkan terbengkalai atau dimanfaatkan untuk kepentingan lain yang sedikit banyak "merusak" fisik benteng itu sendiri. Beberapa benteng yang sudah tidak digunakan lagi oleh ABRI (Benteng VOC di Jepara dan Benteng Karangbolong di Pulau Nusakambangan) hanya dibiarkan terbengkalai, sehingga lambat laun menjadi semakin rusak, baik karena alam maupun manusia.

Sementara itu terdapat benteng-benteng yang sudah mulai dimanfaatkan untuk obyek wisata (Benteng Pendem di Cilacap dan Benteng Portugis di Jepara), namun pemanfaatannya belum sepenuhnya mengacu pada kaidah pemanfaatan yang berlaku. Tidak berarti bahwa upaya-upaya penanggulangan belum dilakukan, tetapi hal itu cukup sulit untuk dilakukan mengingat status kepemilikan benteng-benteng tersebut. Karena status kepemilikannya masih berada di tangan ABRI (sebagian besar), maka banyak hal yang harus dijadikan bahan pertimbangan.

\section{PENUTUP}

Melihat kenyataan bahwa masih cukup banyak benteng yang masih berdiri hingga saat ini --meskipun dalam kondisi yang tidak terlalu baik--, diharapkan dapat dilakukan upaya-upaya untuk mencegah semakin turunnya kualitas sumberdaya arkeologi tersebut, meskipun terdapat kendala-kendala dalam upaya pelaksanaannya.Untuk 
mencegah semakin turunnya kualitas sumberdaya arkeologi yang berupa bekas-bekas benteng --utamanya di Jawa Tengah-- dapat dikemukakan beberapa hal sebagai berikut: sebagai langkah awal tentunya perlu diupayakan inventarisasi maupun penelitian yang cukup lengkap dan menyeluruh terhadap tinggalan-tinggalan tersebut. Selanjutnya langkah ini hendaknya diikuti pula dengan penerbitan SK BCB sebagai "pengikat" bagi para pengguna ataupun pengelola bangunan-bangunan tersebut. Namun demikian, mengingat sebagian besar benteng tersebut masih berada di bawah pengelolaan ABRI, belum diketahui apakah diperlukan kebijakan khusus di tingkat yang lebih tinggi dalam menangani kasus benteng-benteng ini. Selanjutnya kelestarian benteng-benteng ini juga tergantung pada realisasi UU RI No. 4/1982 dan PP 10.1993 pasal 44 dalam perencanaan pengembangan suatu kota/wilayah (RUTRK dan RDTRK). Dalam kasus-kasus yang terjadi di beberapa kota (misalnya Surakarta dan Boyolali) terlihat bahwa berbagai perundangan tersebut belum diperhitungkan. Khusus untuk kasus yang terjadi di Boyolali, hal itu dapat dimengerti, karena peruntuhan benteng Renovatum tersebut dilakukan pada tahun 1953, jauh sebelum berbagai perundangan beserta PP dan Kepmen yang berkaitan itu diundangkan. Akan tetapi apa yang terjadi dengan Benteng Vastenburg di Surakarta seyogyanya dapat dicegah apabila undang-undang beserta ketentuan ikutannya tersebut benar-benar dipahami dan direalisasikan sepenuhnya dalam perencanaan pengembangan kota. Dalam hal ini. masalahnya adalah bahwa sejauh ini belum banyak dilakukan penelitian maupun inventarisasi atas berbagai bangunan bergaya Indis. Selain itu informasi hasil penelitian arkeologi maupun inventarisasi BCB (khususnya yang menyangkut bangunan Indis) belum sepenuhnya digunakan sebagai acuan dalam perencanaan pembangunan lintas sektoral di wilayah dan juga masih kurangnya pemahaman UU RI No. 5/1992 dan segala ketentuan ikutannya oleh para teknokrat perencana dan pengambil keputusan di jajaran tingkat I dan II. Padahal potensi dan nilai penting BCB sebagai aset pembangunan baik dalam skala nasional, provinsional, maupun lokal harus diperhitungkan dan dipertimbangkan sepenuhnya dalam pembangunan wilayah, khususnya yang tertuang dalam penyusunan Rencana Umum Tata Ruang (RUTR) dan Rencana Detil Tata Ruang (RDTR) di tingkat I dan II, bahkan dalam Rencana Umum Tata Bangunan (RUTB) dan Rencana Detil Tata Bangunan (RDTB) di tingkat II dan kecamatan. 


\section{KEPUSTAKAAN}

Abbas, Novida 1993/1994. Laporan Hasil Penelitian Arkeologi Survei Arsitektur Benteng Kolonial di Grobogan, Salatiga, Boyolali, dan Surakarta, Provinsi Jawa Tengah (Tahap I). Balai Arkeologi Yogyakarta.

1994/1995. Laporan Hasil Penelitian Arkeologi Survei Sarana Pertahanan Kolonial di Kabupaten Jepara dan Kabupaten Semarang, Provinsi Jawa Tengah (Tahap II). Balai Arkeologi Yogyakarta.

1995/1996. Laporan Hasil Penelitian Arkeologi - Survei Sarana Pertahanan Kolonial di Kotamadia Pekalongan, Kabupaten Kebumen, dan Kabupaten Cilacap, Provinsi Jawa Tengah (Tahap III). Balai Arkeologi Yogyakarta.

Abbas, Novida. 1996/1997. Penempatan Benteng Kolonial di Kota-kota Abad XVII-$X I X$ di Jawa Tengah, dalam Jurnal Penelitian Arkeologi No. 04. Balai Arkeologi Yogyakarta, pp. 47--52.

Darmosoetopo, Riboet, dkk. 1983. Studi Kelayakan Benteng Willem II Ungaran. Yogyakarta: Proyek Pemugaran dan Pemeliharaan Peninggalan Sejarah dan Purbakala Jawa Tengah.

Graaf, H.J. de. 1987. Runtuhnya Istana Mataram. Jakarta: P.T. Pustaka Utama Grafiti.

Hatmosuprobo, Suhardjo. 1979. Kota Yogyakarta dan Benteng Vredeburg. Yogyakarta : Team Peneliti Vredeburg, Lembaga Studi Pedesaan dan Kawasan dari Universitas Gadjah Mada.

Hooyer, G.B. 1896. De Krijgsgeschiedenis van Nederlandsch-Indie van 1811 tot 1894, I. Den Haag-Batavia.

Humas Kabupaten Dati II Boyolali. tanpa tahun. Sejarah Singkat Hari Jadi Kabupaten Boyolali. Tidak diterbitkan.

Olthof, W.L. 1941. Poenika Serat babad Tanah Djawi Wiwit Saking Nabi Adam Doemoegi ing Taoen 1647. "s-Gravenhage: M. Nijhoff. 
Schiffer, Michael B. \& George J. Gummerman. 1977. Conservation Archaeology, A Guide for Cultural Resources Management Studies. New York: Academic Press.

Soekiman, Djoko. 1996. Kebudayaan Indis dan Gaya Hidup Masyarakat Pendukungnya di Jawa (Abad XVIII sampai Medio Abad XX). Disertasi. Universitas Gadjah Mada.

Soetjipto, F.A. (ed.). 1975. Sejarah Nasional Indonesia IV. Jakarta: PT Grafitas.

Suara Merdeka. Sekitar Bangunan Kuno di Solo. 1 \& 2 November 1994.

Tjandrasasmita, Uka. (ed.). 1984. Sejarah Nasional Indonesia III. Jakarta: PN Balai Pustaka. 